\title{
THE ROLE OF AIR TRANSPORT DEVELOPMENT IN ADRIATIC- IONIAN MACROREGION
}

\author{
Olja Čokorilo' ${ }^{1}$, Ivana Čavka \\ 1,2 University of Belgrade, Faculty of Transport and Traffic Engineering, Vojvode Stepe 305, 11000 \\ Belgrade, Serbia
}

Received 22 July 2015; accepted 9 September 2015

\begin{abstract}
The main objective of the proposed research is to improve the accessibility and the mobility of passengers across the Adriatic area and its hinterland, through the development of new sustainable and integrated transport services and the improvement of physical infrastructures related to those new services, particulary in the air transport connectivity and accesability. Analysis is oriented on existing infrastructure, connections and available aircraft fleet capacities based on three possible scenarios which are identified on the recommendations of renominated statistical data (Eurocontrol, Boeing, Airbus). Microregional improvements could be the key drivers for the macro economical issues where air transport plays significant role. Aircraft fleet, load factor and tourist destination atractivnes significantly improve hinterlend connectivities within Adriatic ports for both ferry and cruise passengers.
\end{abstract}

Keywords: air transport, hinterland, Adriatic region.

\section{Introduction}

Hinterland connections in Adriatic-Ionian macroregion that covers coastal areas in six different countries (Italy, Slovenia, Croatia, Montenegro, Albania and Greece) are a precondicion of ports development in this region. The paper provides the evaluation of the integration among Adriatic ports and their hinterland enabled with air transport network that allows identifying needs and priorities, bottlenecks, potentials for passenger transport services/lines and their possible future integrations (Čokorilo et al., 2015).

It is important to notice at this point, road transport which is of the utmost importance for the functioning of ferry and cruiser traffic flows in Adriatic-Ionian region. Expressed flexibility and ability to quickly respond to modern transport demands have enabled the largest share of road transport at the level of the whole transport market. Rapid road transport development can lead to congestions on the main routes in ports as well, and it may have a negative influence on the environment and the health of the population and decrease of traffic safety level. Therefore, it is necessary to make conditions for redirection of the demand to other transport modes with the aim of controlling the excessive development of the road transport.

Railways are important part of European transport system and significant contributor to achieving the sustainable transport in the future. Road and railway traffic networks are an indispensable prerequisite for the development and competitiveness of the ports in the Adriatic-Ionian region.

\footnotetext{
${ }^{1}$ Corresponding author: oljav@sf.bg.ac.rs
} 
New air links within the Adriatic region could also considerably improve mobility and accelerate economic integration and cooperation processes. However, the problem of intraregional connectivity prevails, where majority of destinations from and to the Adriatic airports are in the Western Europe and minor of all air transport operations in the region are realised within the Adriatic network. Underdeveloped connections between the Adriatic ports and major cities represent a barrier for fast and convenient travel within the region.

\section{Literature Review}

Air transport development is a multi functional process which mostly depends on aviation market in terms of regional economic development and liberalization (Graham, 1997; Graham, 1998; Graham and Guyer, 1999; Thompson, 2002). Contemporary regional studies and research are focused mostly on economical aspects due to the touristic development within particular zones (Yamaguchi, 2007; Brooke et al., 1994; Prideaux, 2000). Moreover, some authors are oriented on modeling environmental issues within the certain region (Abeyratne, 1999; Houyoux et al., 2000) or climate change problems (Mickley et al., 2004). Decision makers are more oriented in creating policies which will anable air transport market defragmentation and connectivity improvements (Button et al., 1998; Steiner et al., 2008; Šimecki et al., 2013).

\section{Airports and Air Connections in the Region}

The following chapter elaborates current state of air transport within and outside the Adriatic region through separate analysis divided in two main subchapters. The first subchapter provides assessment of the Adriatic national airlines while the second is focused on the Adriatic basin airports network analysing them through the following topics: a) ownership structures; $b$ ) geostrategic valorisation; c) transportation connectivity; d) infrastructure assessment and e) traffic performance. Additional attention within this chapter is dedicated to historical overview of the global air transport main figures.

\subsection{Assessment of the Adriatic-Ionian National Airlines}

The break-up of Yugoslavia and associated confrontations caused geopolitical and economic changes in the SEE region, which resulted in fragmentation of once unified transport market and accordingly reduction of air transport volumes. Each country independently established their national airlines as well as the hub airports which are situated in the countries capital cities. Due to the unstable political situation within the region supported by the lack of bilateral agreements between the countries, each country established their route network mainly towards the Western Europe countries while intraregional connectivity was neglected.

After signing the ECAA agreement, the air services were liberalised and the route network has grown rapidly. New established routes are connecting European destinations within the Adriatic region serving neighbouring hub airports as feeders while regional main airport, which could compare to European hubs, have been established mainly in Italy. It implicates the lack of domestic traffic, with exception in Italy and Croatia, which highlights the importance of 
cross border international traffic on regional level. Table 1 provides overview of the current list of national airlines in the Adriatic Ionian basin (Čavka and Čokorilo, 2015).

Table 1

List of National Airlines and Related Indicators of Air Transport in the Adriatic-Ionian Basin

\begin{tabular}{|c|c|c|c|c|c|c|}
\hline Country & National airline & Ownership & $\begin{array}{l}\text { Former } \\
\text { ownership }\end{array}$ & $\begin{array}{l}\text { Number of } \\
\text { aircraft }\end{array}$ & $\begin{array}{l}\text { Aircraft } \\
\text { types }\end{array}$ & $\begin{array}{l}\text { Number of } \\
\text { destinations }\end{array}$ \\
\hline Albania & - & - & $\begin{array}{l}\text { Albanian } \\
\text { Airlines, } \\
\text { ceased } \\
\text { operation in } \\
2011\end{array}$ & - & - & - \\
\hline $\begin{array}{l}\text { Bosnia and } \\
\text { Herzegovina }\end{array}$ & B\&H Airlines & $\begin{array}{l}\text { Government } \\
99.93 \%\end{array}$ & - & 2 & 2 ATR $72-212$ & 4 \\
\hline Croatia & Croatia Airlines & $\begin{array}{l}\text { Government } \\
96.22 \%\end{array}$ & - & 12 & $\begin{array}{l}4 \mathrm{~A} 3192 \\
\mathrm{~A} 3206 \mathrm{Q} 400\end{array}$ & 27 \\
\hline Italy & Alitalia & $\begin{array}{l}\text { Fully private } \\
\text { company } \\
\text { with } 24 \\
\text { shareholders }\end{array}$ & - & 103 & $\begin{array}{l}22 \text { A319 } \\
47 \text { A320 } \\
12 \text { A321 } \\
12 \text { A330 } \\
10 \text { B } 777 \\
\end{array}$ & 83 \\
\hline Montenegro & $\begin{array}{l}\text { Montenegro } \\
\text { Airlines }\end{array}$ & $\begin{array}{l}\text { Government } \\
100 \%\end{array}$ & - & 6 & $\begin{array}{l}1 \text { E-190LR } \\
3 \text { E-195LR } \\
2 \text { Fokker } 100\end{array}$ & 13 \\
\hline Slovenia & Adria Airways & $\begin{array}{l}\text { Government } \\
69.9 \%\end{array}$ & - & 10 & $\begin{array}{l}2 \text { A319 } \\
2 \text { CRJ200LR } \\
6 \text { CRJ900LR }\end{array}$ & 23 \\
\hline
\end{tabular}

Main indicators of current state of air transport in the Adriatic region are modes traffic flows that represent $2 \%$ of passenger transportation in the world schedule traffic and $1.5 \%$ of the number of international airports in the world as well as underdeveloped intra-regional connectivity and lack of intercontinental flights (Čavka and Čokorilo, 2015).

Recent territorial fragmentation of the $S E E$ region resulted in the creation of new independent States from which each has established its national flag carrier. Cumulative traffic volume of the SEE airlines $^{2}$ (4.4 million passengers) in the year 2010 was 1.5 times lower than neighbouring

${ }^{2} \mathrm{BH}$ Airlines, Croatia Airlines, Montenegro Airlines, Air Serbia (ex. JAT Airways)
Austrian Airlines traffic volume (10.9 million passengers). It reflects enormous change considering a pre-war period (1989) when Yugoslavian JAT alone carried double passengers than Austrian Airlines.

Due to low performance of national airlines, private sector incursion started in 1997 transposing Albanian Airlines shares to M.A. Kharafi \& Sons group. The process continued in 2008 by its further transposing to Advanced Construction Group ( $\mathrm{ACG}^{3}$ ) and soon after in 2009 to Azerbaijan based Turkish Evsen Group of Companies (93\%) while $7 \%$ remained in ACG. However, it could be stated that mentioned privatisation was not successful as Albania's Civil Aviation ${ }^{3}$ ACG - Advanced Construction Group 
Authority took the decision in November 2011 to revoke the operating license of Albanian Airlines leading to a suspension of flights operated by the company.

Unsuccessful privatisation of public transport companies in the SEE region continued in 2008 by Turkish Airlines acquiring 49 percent of the $\mathrm{BH}$ airlines from the Government of Bosnia and Herzegovina that lasted until mid 2012 when Turkish Airlines cancelled the agreement with $\mathrm{BH}$ Airlines due to inability of BH Government to invest in the joint venture.

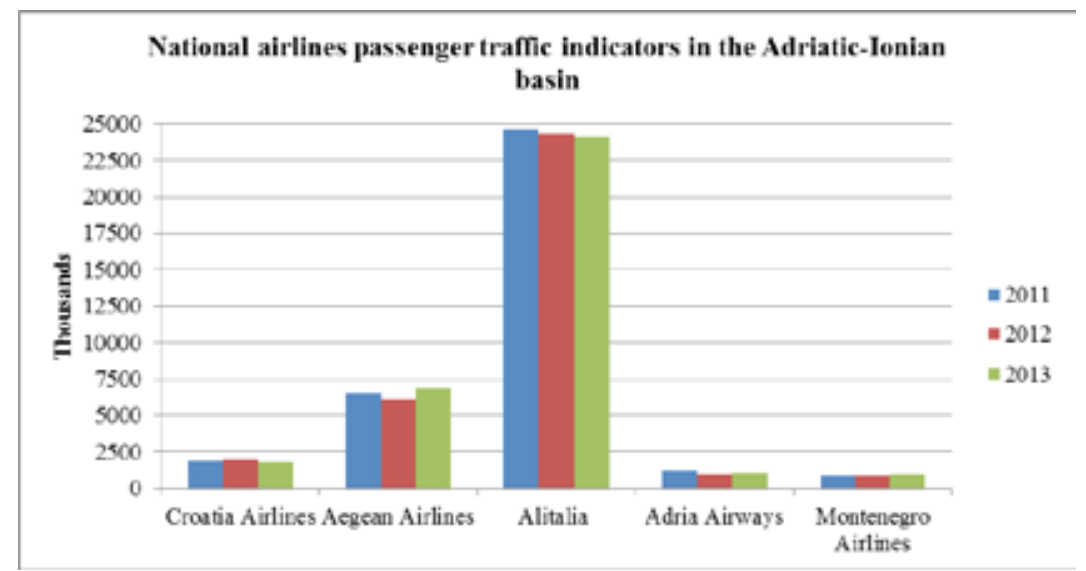

Fig. 1.

Indicators of Passenger Traffic Carried by National Airlines in the Adriatic Basin

Fig. 1 shows that Alitalia is the leading airline (in terms of passengers) in the Adriatic region. Albanian Airlines recorded the highest traffic growth in 2010, three times higher than in 2009 due to visa liberalisation with the EU countries, which entered into force in 2010, but as previously mentioned, it ceased operations in 2011.

\subsection{Assessment of Adriatic-Ionian Basin Airports Network}

The most conspicuous strategic advantage of the Adriatic region can be defined through the typical characteristic of the region which is placed at the active confluence of three regions - the Balkan peninsula, Caucasus and Asia, which are all very close to the growing market of Middle East. The Adriatic region has a favourable geo-strategic position for attracting air traffic in over-flights and regarding the projection of traffic growth between Northwestern Europe and the Mediterranean and the Near East.

However, small size of national aviation markets in the Adriatic countries and the geographical location of many airports positioned close to national borders have impact on passenger air traffic volumes in the region as well as on intraregional air transport connectivity (Table 2). Also, the competition among the airports with overlapping hinterlands can be fostered by improving road and rail links and crossborder procedures. 
Table 2

Adriatic-Ionian Network Airports Considered among Regional Participants

\begin{tabular}{|l|l|}
\hline \multirow{4}{*}{ Country } & Adriatic-Ionian network airports \\
\hline \multirow{4}{*}{ Croatia } & Dubrovnik \\
\cline { 2 - 2 } & Pula \\
\cline { 2 - 2 } & Rijeka \\
\cline { 2 - 2 } & Split \\
\hline \multirow{4}{*}{ Greece } & Corfu \\
\hline \multirow{4}{*}{ Italy } & Trieste \\
\cline { 2 - 2 } & Bari \\
\cline { 2 - 2 } & Ancona \\
\cline { 2 - 2 } & Venice \\
\cline { 2 - 2 } & Pescara \\
\hline Montenegro & Tivat \\
\hline Slovenia & Portorož \\
\hline
\end{tabular}

The catchment areas of the airports in countries while the highest airport density the Adriatic region are shown on Fig. 2. is registered in Southeastern part of the Airport catchment areas $(100 \mathrm{~km})$ in the region where seven airports are situated in region spread to one or more neighbouring the radius of 220 kilometres.

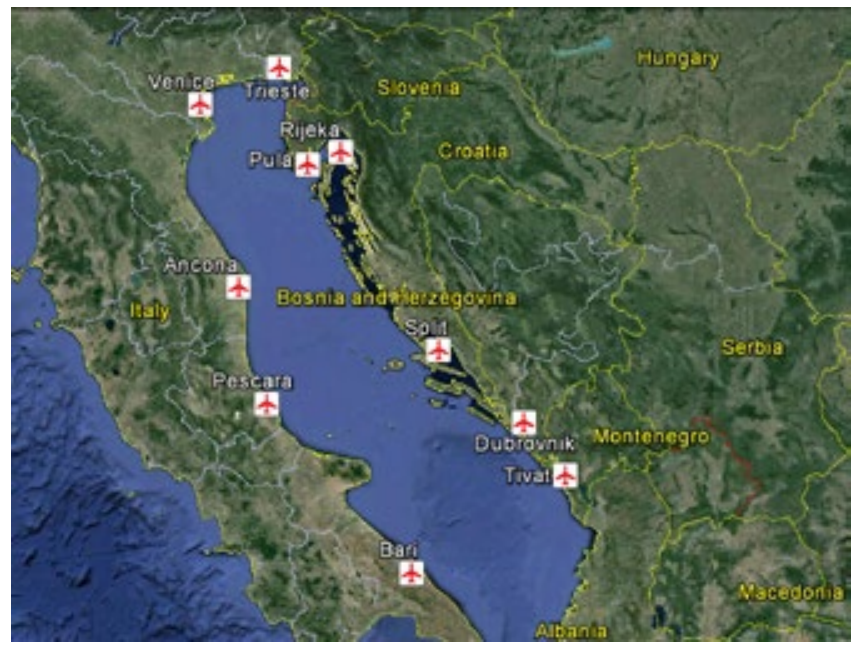

Fig. 2.

Airport Catchment Areas in the Adriatic Basin

In South-Western (Rijeka and Pula) and Southern (Split and Zadar) part of Croatia direct catchment overlapping is perceived and it limits mentioned airports further development. In North-Eastern part of the SEE region, where lowest airport density and highest population density (7.5 million inhabitants) is perceived, the majority of 
traffic is concentrated on Belgrade Airport (UNECE, 2015). Sarajevo Airport by its geostrategic position is in the middle of the SEE region has an opportunity to serve as a regional connecting point; but due to bad weather conditions and direct catchment of 750,000 inhabitants its traffic volumes are limited.

By applying TEN-T categorisation on the airports in the Adriatic region it can be noted that, on the basis of their traffic performance, Venice airport is considered as International connecting point, other 4 could be in the second category as Community connecting points (Dubrovnik, Split, Bari, Corfu), while other 7 (Rijeka, Pula, Tivat, Trieste, Ancona, Pescara and Portorož) are in the third category as Regional connecting points. Main infrastructure and traffic indicators are shown in Table 3 and Table 4.

Table 3

Infrastructure Indicators

\begin{tabular}{|l|l|l|l|}
\hline Airport & Number of runways & Main runway length $(\mathbf{m})$ & Number of passenger terminals \\
\hline Trieste & 1 & 3000 & 1 \\
\hline Dubrovnik & 1 & 3,300 & 1 \\
\hline Pula & 1 & 2,946 & 1 \\
\hline Bari & 2 & 2,820 & 1 \\
\hline Ancona & 1 & 2,962 & 1 \\
\hline Rijeka & 1 & 2,500 & 1 \\
\hline Venice & 2 & 3,300 & 1 \\
\hline Pescara & 1 & 2,419 & 1 \\
\hline Portorož & 1 & 1,201 & 1 \\
\hline Tivat & 1 & 3,252 & 1 \\
\hline Tirana & 1 & 2,750 & 1 \\
\hline Split & 1 & 2,550 & 1 \\
\hline Corfu & 1 & 2,373 & 1 \\
\hline
\end{tabular}

Table 4

Indicators of Passenger and Cargo Traffic

\begin{tabular}{|c|c|c|c|c|c|c|}
\hline \multirow{2}{*}{ Airport } & \begin{tabular}{|l|} 
Passengers \\
\end{tabular} & Cargo (t) & \begin{tabular}{|l|} 
Passengers \\
\end{tabular} & Cargo (t) & \begin{tabular}{|l|} 
Passengers \\
\end{tabular} & Cargo (t) \\
\hline & \multicolumn{2}{|l|}{2011} & \multicolumn{2}{|l|}{2012} & \multicolumn{2}{|l|}{2013} \\
\hline Trieste & 857,134 & - & 880,543 & - & 853,981 & - \\
\hline Dubrovnik & $1,356,036$ & 389 & $1,490,844$ & 344 & $1,526,841$ & 294 \\
\hline Pula & 351,394 & 2 & 375,979 & 4 & 359,490 & 3 \\
\hline Bari & $3,724,058$ & 2,127 & $3,791,977$ & 1,999 & $3,601,377$ & 2,033 \\
\hline Ancona & 606,591 & 6,997 & 564,476 & 6,864 & 501,689 & 6,680 \\
\hline Rijeka & 78,890 & - & 72,762 & - & 140,776 & - \\
\hline Venice & $8,572,909$ & 32,695 & $8,192,296$ & 33,112 & $8,401,085$ & 37,728 \\
\hline Pescara & 550,062 & 1,200 & 563,187 & 1,221 & 548,217 & 721,1 \\
\hline Portorož & 21,263 & - & - & - & - & - \\
\hline Tivat & 647,169 & - & 725,392 & - & 868,423 & - \\
\hline Tirana & $1,817,073$ & 2,656 & $1,665,331$ & 1,875 & $1,757,342$ & 2,164 \\
\hline Split & $1,302,084$ & 619 & $1,424,013$ & 577 & $1,587,264$ & 450 \\
\hline Corfu & - & - & - & - & $2,383.353$ & - \\
\hline
\end{tabular}




\section{Air Transport Capacity and Facts}

Air transport capacity has been one of the major trends investigated in contemporary air transport development. Many of capacity indicators are the basis for huge infrastructure investments as well as for passenger capacity growth. Main indicators are based on measuring: IFR flights forecast by EUROCONTROL, GDP in the observed zones (Eurostat, 2013), GDP by flights and other relevant parameters (local airports statistics), relevant economic facts (Eurostat, 2013), fares, travel time, etc.

\section{1. Historic Air Passenger Traffic Trends}

Fig. 3 illustrates the relative growth or decline in airport passenger throughput market share, by global region, between 2002 and 2012. From the graphic it is immediately apparent that over the last decade there has been a demonstrable shift in the focus of growth in a regional context.

By analyzing global airport passenger traffic data from ACI, we can observe that the European market was a clear second, some distance behind North America but also significantly ahead of Asia Pacific, which, at this stage, was a relatively immature market yet to unlock its full potential.

Fast forward ten years to 2012 and the landscape has changed as Asia Pacific, dominated by vast, rapidly growing domestic markets in China, India and Indonesia, has transformed the region on the global stage. 2012, for the first time, saw Asia Pacific assume status as the leading global air transport market.

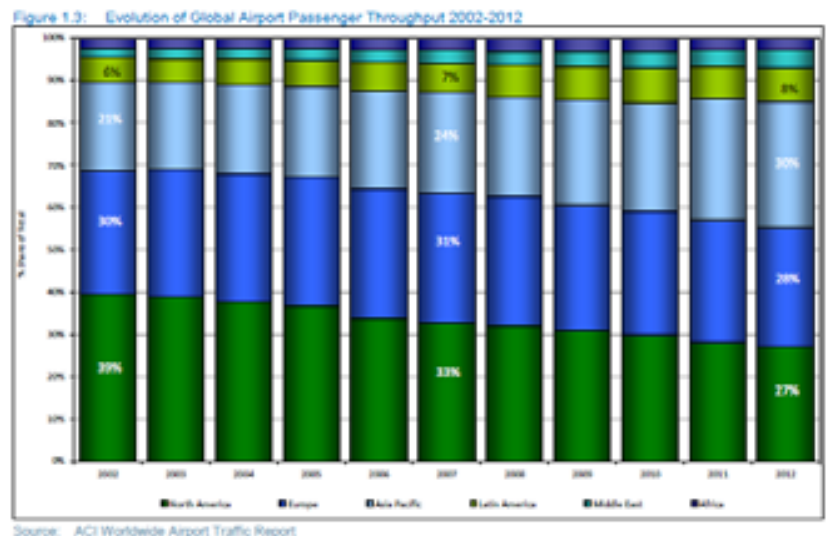

Fig. 3.

Evolution of Global Airport Passenger Throughput 2002-2012

Source: ACI Worldwide Airport Traffic Report

Placing air passenger traffic growth in 2012 in a historical context, we can see that over the course of the last decade the underlying trend has been one of positive growth, albeit fairly erratic due to a variety of external 'shock' events. The industry declines experienced in 2003, 2009 and 2011 (mainly attributable to the SARS 
epidemic, global economic downturn and 'Arab Spring', respectively) remind us that air travel demand is explicitly vulnerable to exogenous events. Equally evident is the resilience of the industry in 'bouncing back' after these shocks - note the sharp increase in overall growth in 2004 and 2010, in particular, following the shocks of the preceding years.

\subsection{The European Air Transport Market}

Within Europe, there is considerable variety in the volume of air passenger traffic at an individual country basis. Fig. 4 ranks the 27 EU member states in 2012 according to size of air transport market, and compares against ECAA states and neighbouring Turkey and Russia.

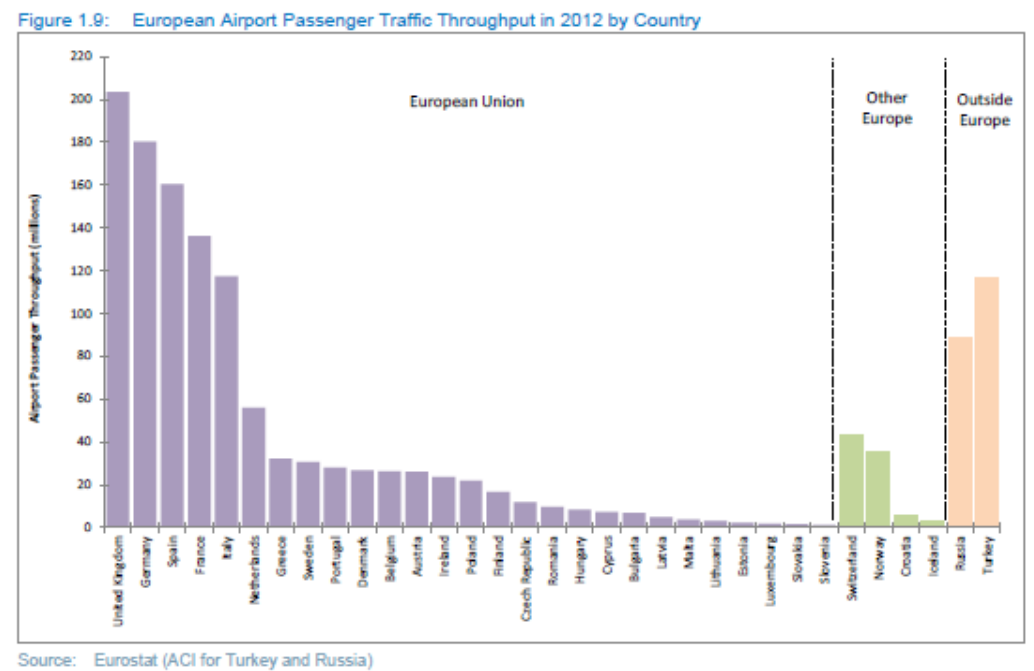

Fig. 4.

European Airport Passenger Traffic Throughput in 2012 by Country

Source: Eurostat (2015) (ACI for Turkey and Russia)

Combined, UK, Germany, Spain, France and Italy, these EU member states accounted for $70 \%$ of the European Union total airport passenger throughput in 2012. The remaining $30 \%$ is distributed among 22 member states, highlighting the two tier hierarchy that exists between the mature and emerging markets within the bloc. It is interesting to note that neighbouring Turkey and Russia have expanded their air transport markets in recent years to the extent that they now rival the top five EU countries in terms of passenger volumes. Furthermore, given the rate of expansion in Turkey and Russia, the gap may reasonably be expected to close further in the near future. This trend is illustrated in following figure where we see growth in the Russian and Turkish air transport markets in 2012 versus 2011 outpacing all but two of the EU27 countries. 


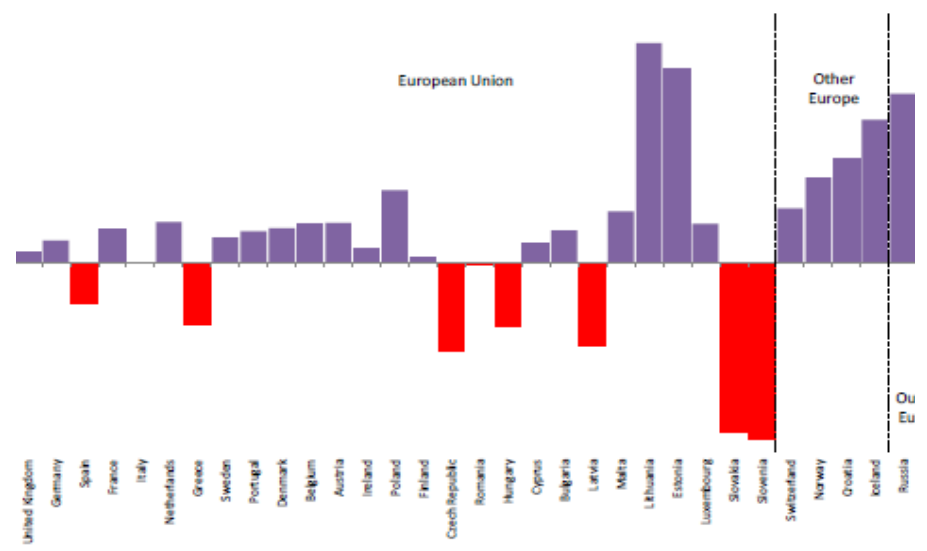

Fig. 5.

European Airport Passenger Traffic Growth 2012 vs. 2011 by Country

Source: Eurostat (2015) (ACI for Turkey and Russia)

The European Union Member States recording the highest growth in 2012 included Lithuania (17\%) and Estonia (15\%), reinforcing their strong performances in 2011. However, no fewer than nine of the EU27 experienced declines in 2012. The most significant of these, due to the relative size of the markets, are Spain and Greece - the economic woes of both being well documented, and having a continued negative impact on air travel demand. Although the declines in the Slovakian and Slovenian markets look dramatic in Fig. 5, the markets are small $(1.6 \mathrm{~m}$ and $1.2 \mathrm{~m}$ passengers in 2012, respectively) so any movement in the airport passenger throughput is going to be amplified.

In the case of Slovakia, Bratislava in particular felt a hit with CSA Czech Airlines and Ryanair both cutting capacity. In Slovenia, Ljubljana traffic was negatively impacted by Adria Airways downsizing on some key routes such as Paris, London and Istanbul.
The relationship between economic growth and air travel demand can be used to justify the growth or decline in some markets (such as Spain, Italy, Greece, Turkey and Russia) but other factors including air transport market maturity; airport capacity and congestion; the policy and regulatory environment; low cost carrier stimulation; and taxation and pricing regimes will all contribute to affecting the demand for air travel, creating an uneven playing field throughout Europe allowing certain markets to flourish while others decline.

Table 5 observes the historical growth of passenger traffic in the $\mathrm{EU}$ and neighbouring countries, between 2007 and 2012. The immediate point to make is that nine out of the $27 \mathrm{EU}$ member states have experienced a declining trend in air passenger traffic during this period - an alarming statistic that reveals the depth of the impact of economic and financial crisis spreading across the region from 2008 , severely denting demand for air travel in certain European markets. 
Table 5

Historical European Airport Passenger Traffic Throughput by Country (Millions)

\begin{tabular}{|c|c|c|c|c|c|c|c|c|}
\hline Country & 2007 & 2008 & 2009 & 2010 & 2011 & 2012 & $\begin{array}{l}\text { Change } \\
' 12 v ' 11\end{array}$ & $\begin{array}{l}\text { CAGR 2007- } \\
2012\end{array}$ \\
\hline UK & 218.6 & 214.9 & 199.2 & 193.5 & 202.0 & 203.5 & $0.8 \%$ & $-1.4 \%$ \\
\hline Germany & 165.9 & 167.8 & 160.6 & 168.8 & 177.1 & 190.3 & $1.8 \%$ & $1.7 \%$ \\
\hline Spain & 163.0 & 162.2 & 149.0 & 153.9 & 165.7 & 160.4 & $-3.2 \%$ & $-0.3 \%$ \\
\hline France & 120.3 & 122.7 & 117.6 & 126.3 & 132.6 & 136.2 & $2.7 \%$ & $2.5 \%$ \\
\hline Italy & 108.7 & 106.5 & 103.3 & 110.7 & 117.5 & 117.4 & $-0.1 \%$ & $1.5 \%$ \\
\hline Netherlands & 50.8 & 50.7 & 46.7 & 48.9 & 54.2 & 55.9 & $3.2 \%$ & $2.0 \%$ \\
\hline Greece & 34.8 & 35.1 & 33.4 & 32.6 & 33.8 & 32.1 & $-5.0 \%$ & $-1.6 \%$ \\
\hline Sweden & 27.3 & 28.1 & 25.4 & 26.9 & 29.9 & 30.6 & $2.0 \%$ & $2.3 \%$ \\
\hline Portugal & 24.1 & 24.8 & 23.8 & 25.4 & 27.2 & 27.9 & $2.5 \%$ & $3.0 \%$ \\
\hline Denmark & 21.2 & 24.5 & 22.4 & 24.5 & 25.9 & 26.7 & $2.7 \%$ & $2.0 \%$ \\
\hline Belgium & 21.0 & 22.3 & 21.7 & 23.0 & 25.4 & 26.2 & $3.1 \%$ & $4.5 \%$ \\
\hline Austria & 23.1 & 24.1 & 22.0 & 23.7 & 26.3 & 26.1 & $3.2 \%$ & $2.5 \%$ \\
\hline Ireland & 30.1 & 30.2 & 26.4 & 23.2 & 23.4 & 23.6 & $1.1 \%$ & $-4.7 \%$ \\
\hline Poland & 17.2 & 18.7 & 17.1 & 18.4 & 20.7 & 21.9 & $5.8 \%$ & $5.0 \%$ \\
\hline Finland & 14.4 & 14.8 & 13.8 & 14.3 & 16.4 & 16.5 & $0.4 \%$ & $2.7 \%$ \\
\hline Czech R. & 13.3 & 13.6 & 12.6 & 12.4 & 12.8 & 11.9 & $-7.0 \%$ & $-2.1 \%$ \\
\hline Romania & 7.0 & 8.1 & 8.0 & 8.9 & 9.8 & 9.7 & $-0.3 \%$ & $6.9 \%$ \\
\hline Hungary & 8.6 & 8.4 & 8.1 & 8.2 & 8.9 & 8.4 & $-5.1 \%$ & $-0.4 \%$ \\
\hline Cyprus & 7.3 & 7.6 & 7.0 & 7.2 & 7.2 & 7.3 & $1.5 \%$ & $0.0 \%$ \\
\hline Bulgaria & 6.1 & 6.4 & 5.9 & 6.2 & 6.7 & 6.9 & $2.6 \%$ & $2.4 \%$ \\
\hline Latvia & 3.2 & 3.7 & 4.1 & 4.7 & 5.1 & 4.8 & $-6.6 \%$ & $8.5 \%$ \\
\hline Malta & 3.0 & 3.1 & 2.9 & 3.3 & 3.5 & 3.7 & $4.1 \%$ & $4.2 \%$ \\
\hline Lithuania & 2.2 & 2.6 & 1.9 & 2.3 & 2.7 & 3.2 & $17.5 \%$ & $7.6 \%$ \\
\hline Estonia & 1.7 & 1.8 & 1.3 & 1.4 & 1.9 & 2.2 & $15.4 \%$ & $5.0 \%$ \\
\hline Luxembourg & 1.6 & 1.7 & 1.6 & 1.6 & 1.8 & 1.9 & $3.1 \%$ & $3.0 \%$ \\
\hline Slovakia & 2.3 & 2.6 & 1.9 & 1.9 & 1.8 & 1.6 & $-13.5 \%$ & $-7.1 \%$ \\
\hline Slovenia & 1.5 & 1.7 & 1.4 & 1.4 & 1.4 & 1.2 & $-14.1 \%$ & $-5.2 \%$ \\
\hline EU-27 & 792.7 & 798.3 & 751.1 & 821.3 & 826.7 & 826.7 & $0.7 \%$ & $0.8 \%$ \\
\hline Switzerland & 34.8 & 36.8 & 36.1 & 37.7 & 41.6 & 43.4 & $4.3 \%$ & $4.5 \%$ \\
\hline Norway & 27.9 & 29.0 & 28.1 & 30.0 & 33.0 & 35.2 & $6.8 \%$ & $4.8 \%$ \\
\hline Croatia & & 4.6 & 4.4 & 4.7 & 5.0 & 5.5 & $8.3 \%$ & $4.5 \%$ \\
\hline Iceland & 2.5 & 2.2 & 1.9 & 2.1 & 2.5 & 2.8 & $11.4 \%$ & $2.3 \%$ \\
\hline Russia & 71.6 & 79.1 & 54.4 & 66.9 & 65.2 & 88.9 & $36.4 \%$ & $4.4 \%$ \\
\hline Turkey & 61.4 & 72.5 & 79.8 & 92.9 & 105.9 & 116.7 & $10.2 \%$ & $12.7 \%$ \\
\hline
\end{tabular}

Source: Eurostat (ACI for Turkey and Russia); [ ${ }^{*}$ EU27 total removes double counting]; [ ${ }^{* *} A A G R$ 2008-2012] 


\section{Scenario Analysis for Air Transport}

Due to the lack of intraregional connectivity within the Adriatic basin, certain parts of the region have limited access to regional, European and global markets. Mentioned imbalance of accessibility to services, markets and opportunities for further social and economic progress is an obstacle for overall development of the Adriatic region.

According to available statistics, it is projected that in Europe passenger traffic will rise at an annual rate of $3.8 \%$ to 2032, reaching 2.35 trillion RPK. This is a downward revision of the European market which, in the previous forecast, was estimated to grow to 2.88 trillion in 2030. This decrease is largely due to the performance of the aviation market in the base years; 1.22 trillion RPK in 2010 in contrast to 1.11 trillion RPK in 2012. The core reason for the under-performance is the effect of the economic downturn that has impacted the European region since 2008/2009. The IHS Global Insight GDP forecast for Europe for the years 2012 to 2032 estimate a $2 \%$ annual increase against $1.9 \%$ projected between 2010 and 2030, thus showing increasing confidence in improving economic conditions going forward.

The existing connectivity network and air transport frequencies within the Adriatic region are bellow growing needs and demands of the travelling public. While connections with main European destinations are dominant and all leading European air carriers already operate in the Adriatic region, presently less than $15 \%$ of all airlines commercial activities are realised within the Adriatic network. Therefore, an underdeveloped connection between individual capitals and major cities of the
Adriatic region represents a barrier for fast and convenient travel within the region.

Key determinants of air transport connections development are based on contracts for the joint operations of air carriers and associated partners within airline alliances. Star Alliance, with Austrian Airlines, Lufthansa, Croatia Airlines and Adria Airways as members, dominates in this region, particularly within SEE area (Mantecchini et al., 2013). Accordingly, the highest frequency air transport connections in the Adriatic region are linking the Adriatic region and Western Europe, with the largest number of flights to European nodal airports (Rome, Frankfurt, Munich and Vienna). Whilst number of destinations served from airports in Slovenia, Croatia, Montenegro, Albania coast are less than 50 per airport (for example: Rijeka-10 destinations in 2010, Split-50 destinations in 2010, Tivat-11 destinations in 2010, Dubrovnik-49 destinations in 2010, Tirana-35 destinations in 2010), Italian coast is more developed by the number of served destinations (for example: Bari-32 destinations in 2014, Venice-64 destinations in 2014).

Passengers travelling by air have to consider fixed time blocks, respecting their duration, mostly set by air transport. One of the major disadvantages of air transport to rail and to some extent to road is the check in time, asking the passengers to be at the airport much sooner before the actual flight. In general, for European airports it is two hours for economy travellers on international flights and about 90 minutes for domestic. Travel time used in analysis is calculated as a sum of waiting time at the airport before the flight, flight time and waiting time at the airport after the flight. Time spent at the seasonal airports in Adriatic basin before 
and after the flight (45 minutes) is lower in comparison to European airports due to its smaller capacity and volume of traffic.

\subsection{Development Projects and Scenario Development}

The analysis of the future air transport development of the Adriatic basin is neither possible from the regional, national or EU integrated view but by an assessment from an international perspective. The valuation basis is the macroeconomic valence of the economic instrument: aeronautics as a means of transport for persons and high-quality goods. The possible socio-economic effects at a national and regional level are only then assessable if the international possibilities for development are known and the prerequisites necessary for it were defined.

\subsubsection{Transport Modal Cooperation}

Air transport is not possible without the other means of transport. These serve as conveyer and distributor. The national air traffic services are in demand of the road and railway traffics ahead of all things. Because of the dimension of the catching and target areas of the air traffic passengers and the airfreights, a narrow networking of the airports as an interface to the road and railway traffic is an indispensable prerequisite for the development and competitiveness of an airport. This is obliged to the interests of the respective country and the international interests as a national instrument tied regionally. With the integration of the surface-bound transport services in aeronautics these traffics also undergo their internationalisation and the operative and administrative necessities connected with the integration.

\subsubsection{International Airports and Local Influence}

A usual analysis of the international airports as a municipal traffic location by the local government politics, because of the high political importance for dedicated politicians of the commune or region, makes these frequently forget that today certainly the needs of these locations cannot be satisfied with the assessment bounds of the municipal or regional possibilities. On the contrary necessities are given, which exceed the fortune of the municipal or regional finances. By then visible limitations have been the reasons in many cases that within a limited possibility for development the existing chances were not taken. The egoisms of powerful decision makers are also the reason for undesirable developments in other cases. These are afterwards reversible only by the resulting replacement of main facilitating economic actions with an enormous effort only.

\subsubsection{Intermodal Cooperation}

The great and effortful problems are the coordination of the interests and the obligations of the cooperating traffic carriers. The contractual specification of the cooperation is possible only when the basis of the cooperation is grounded on modular contracts, which contains the possibility of further developing from the regular experiences of the cooperation and facilitating the agreements further in the mutual interest. Narrow-minded attitude to be frequently stated is one of the risks often appearing and reason for the failure of developments to adhere to allegedly indispensable interests and to prevent a flexibility and optimisation of the 
cooperation. Therefore it is necessary to put a high independent authority in charge of the project, whose strategy is not determined by a tactical essential. The principle of the cooperation is the renunciation at the tactical level in favour of a higher profit at the strategic level. The power renunciation at the local and regional level makes the common gain possible at the national and international level.

\subsubsection{Infrastructure Requirements for Flexibility}

1. Not all observed airports are connected to the existing Rail-Network of the region.

2. All airports are capable of serving tourist flights as arriving tourists will be able to reach their final destinations by port, rail or bus services.

3. Short term capacity problems at certain airports are solvable, which excludes high infrastructure investments to serve possible spot problems, leaving finance for long term investments.

\subsection{Scenarios}

The overall goal of future transport development within the Adriatic region should be based on attracting international transport flows and increasing regional development. Air transport is recognized for adequate tool for connecting ports and hinterland due to the easiest of new routes establishment. The existing capacity of airports and aircraft is sufficient for the forthcoming period. As it is shown before, an important parameter of future air transport development is GDP which is evaluate for Europe as $2 \%$ of average increase until 2032. As a key driver in aviation development, this parameter is function of RPK which from the Boeing statistics could be measured round $5 \%$ of growth rate for intra and inter regional flights for the Adriatic region. Air transport has been in constantly growth rate in the last decade.

Some negative aspects within the region are related to the post war development of transport infrastructure in the SEE at the beginning of the last decade which was tightly connected to the national links without a comprehensive regional view. However, in the process of economic development of each country within the region, the need for intraregional accessibility in all aspects became even more important. On the other hand, constant pressure from the European Union (EU) towards the integration of the region and the establishment of political, territorial and economic cohesion became the one of the preconditions for the EU accession process. The EU accession processes have a significant impact on the transport development in the SEE as the EU candidate and potential EU candidate countries need to transpose EU body law into each individual system.

Three potential scenarios are related to air transport development within the Adriatic region:

\section{International and Intercontinental flights development (optimistic scenario} - Best)

It is not possible to expect that the future development of airports in the Adriatic region would be equal for all countries, but there is still great opportunity to develop new routes which will continue to expand the number of potential passengers use ports services. The possible way of future development should be based on hub connectivity (Rome, Milan, Belgrade, Zagreb, etc.) with the expected growth rate of $5 \% \mathrm{RPK}$. 
2. Regional and International flights development (realistic scenario - Modest) This scenario considers existing flights routes between Adriatic region and other European cities. The expected growth rate is evaluated as $2 \%$ of RPK growth, according to GDP and forecast until 2032. This scenario will cover minor growth of passenger using port services, while the growth rate is perceived on the basis of tourist destinations within the region.

\section{Municipal and local oriented airports (pessimistic scenario - Worst)}

This scenario is not expected to be held within the large number of airports within the Adriatic region, but still some future trends should bring reductions in RPK or number of operations for some seasonal airports. Above all, some global economy drivers, Ukrainian crisis, etc. could provide reductions in larger airports but not more than 5\% in the total RPS within the region.

Air transportation has become the key infrastructure for global economic development. Despite uncertainties and potential challenges that may slow down growth, air transport services must continue to expand in a safe, secure, and sustainable manner. This entails substantial investments for markets such as Adriatic region with expected passenger growth to average between 1 and 2 percent annually. However, even less rapidly growing countries must invest in modern airport and air traffic management and surveillance infrastructure. Operators around the globe can only secure sustainable and profitable air services when achieving high energy efficiency through modern aircraft and efficient operations.

\section{Conclusion}

It can be concluded that future measures in infrastructure investments could bring good basis for air transport development as well as touristic attractions. Flexibility in travel time, or speeding up procedures for passengers using cruisers as the preferent travel mode could significantly bring much more passengers in aviation industry. The existing potential is not reach its limits so attractivenes and solutions for modal share are the key drivers for increasing load factor on the existing routes. Moreover, proposed best scenarion would increase air transport services and would open Adriatic-Ionian market to be much more oriented and extended to other regions. All this improvements should accelerate economic integrations via open market issues, revitalization of aviation market dedicated to general aviation and similar, and make the aviation sector more competitive to other modes by opening new lines within the region and wider.

\section{Acknowledgements}

This paper is based on the Europe Adriatic SEA-WAY project, co-financed by the European Union in the framework of the IPA Adriatic Cross-Border Cooperation Programme 2007-2013.

\section{References}

\footnotetext{
Abeyratne, R.I. 1999. Management of the environmental impact of tourism and air transport on small island developing states, Journal of Air Transport Management. DOI: http://dx.doi.org/10.1016/S0969-6997(98)000349, 5(1): 31-37.
} 
Brooke, A.S.; Caves, R.E.; Pitfield, D.E. 1994. Methodology for predicting European short-haul air transport demand from regional airports: An application to East Midlands International Airport, Journal of Air Transport Management. DOI: http://dx.doi. org/10.1016/0969-6997(94)90029-9, 1(1): 37-46.

Button, K.; Haynes, K.; Stough, R. 1998. Flying into the future: air transport policy in the European Union. Edward Elgar Publishing. 199 p.

CE Delft; INFRAS; Fraunhofer ISI. 2011. External Costs of Transport in Europe, Update Study for 2008 Report, Delft, CE Delft. 161 p.

Čavka, I.; Čokorilo, O. 2015. Air transport development within the Adriatic Basin. In Proceedings of the 17th International Conference on Transport Science ICTS 2015, Portorož, Slovenia. 17-27.

Čokorilo, O.; Ivković, I.; Čavka, I.; Twrdy, E.; Zanne, M.; Ferizović, A. 2015. Hinterland Connections of Adriatic-Ionian Region. In Proceedings of the International Scientific Conference - Cooperation Model of the Scientific and Educational Institutions and the Economy, Zagreb, Croatia. 61-67.

Eurostat. 2015. Available from Internet: <http:// ec.europa.eu/eurostat $>$.

Graham, B. 1997. Regional airline services in the liberalized European Union single aviation market, Journal of Air Transport Management. DOI: http://dx.doi. org/10.1016/S0969-6997(97)00032-X, 3(4): 227-238.

Graham, B. 1998. Liberalization, regional economic development and the geography of demand for air transport in the European Union, Journal of Transport Geography. DOI: http://dx.doi.org/10.1016/S09666923(98)00003-9, 6(2): 87-104.
Graham, B.; Guyer, C. 1999. Environmental sustainability, airport capacity and European air transport liberalization: irreconcilable goals?, Journal of Transport Geography. DOI: http://dx.doi.org/10.1016/ S0966-6923(99)00005-8, 7(3): 165-180.

Houyoux, M.R.; Vukovich, J.M.; Coats, C.J.; Wheeler, N.J.; Kasibhatla, P.S. 2000. Emission inventory development and processing for the Seasonal Model for Regional Air Quality (SMRAQ) project, Journal of Geophysical Research: Atmospheres. DOI: http://dx.doi. org/10.1029/1999JD900975, 105(D7): 9079-9090.

Mantecchini, L.; Gualandi, N.; Paganelli, F. 2013. Integration and Concentration of European Air Transport Market, International Journal for Traffic and Transport Engineering. DOI: http://dx.doi.org/10.7708/ ijtte.2013.3(2).08, 3(2): 204-219.

Mickley, L.J.; Jacob, D.J.; Field, B.D.; Rind, D. 2004. Effects of future climate change on regional air pollution episodes in the United States, Geophysical Research Letters. DOI: http://dx.doi.org/10.1029/2004GL021216, 31(24): 1-4.

Prideaux, B. 2000. The role of the transport system in destination development, Tourism Management. DOI: http://dx.doi.org/10.1016/S0261-5177(99)00079-5, 21(1): 53-63.

Steiner, S.; Šimecki, A.; Mihetec, T. 2008. Determinants of European air traffic development, Transport Problems, International Scientific Journal, 3(4): 73-84.

Šimecki, A.; Steiner, S.; Čokorilo, O. 2013. The Accessibility Assessment of Regional Transport Network in the South East Europe, International Journal for Traffic and Transport Engineering. DOI: http://dx.doi. org/10.7708/ijtte.2013.3(4).01, 3(4): 351-364. 
Thompson, I.B. 2002. Air transport liberalisation and the development of third level airports in France, Journal of Transport Geography. DOI: http://dx.doi.org/10.1016/ S0966-6923(02)00043-1, 10(4): 273-285

UNECE - United Nations Economic Commission for Europe database. 2015. Available from Internet: <http://w3.unece.org/PXWeb2015/pxweb/en/STAT/ STAT_40-TRTRANS/?rxid=829c14fc-6f36-4a8aae $40-5443 f 767 e 42 c>$.

Yamaguchi, K. 2007. Inter-regional air transport accessibility and macro-economic performance in Japan, Transportation Research Part E: Logistics and Transportation Review. DOI: http://dx.doi.org/10.1016/j. tre.2006.10.004, 43(3): 247-258. 